\title{
STATUS KEBERLANJUTAN PENGOLAHAN AGROINDUSTRI TEH KELOMPOK TANI BAROKAH DI KECAMATAN CIWIDEY KABUPATEN BANDUNG PROVINSI JAWA BARAT
}

\author{
SUSTAINABILITY STATUS OF AGRO-INDUSTRY PROCESSING \\ BAROKAH TANI GROUP IN CIWIDEY SUB-DISTRICT, BANDUNG DISTRICT, \\ WEST JAVA PROVINCE
}

\author{
Bima Mulia*, Lucyana Trimo, Eti Suminartika \\ Fakultas Pertanian Universitas Padjadjaran \\ *E-mail muliabima@gmail.com \\ (Diterima 20-1-2021; Disetujui 27-1-2021)
}

\begin{abstract}
ABSTRAK
Komoditas teh mempunyai andil penting dalam perekonomian Indonesia yaitu sebagai penyerapan tenaga kerja, sumber pendapatan petani, devisa negara, mendorong agroindustri pengembangan wilayah dan pelestarian lingkungan. Tujuan penelian ini untuk mengetahui dan mengevaluasi status keberlanjutan penggolahan perkebunan teh rakyat kelompk tani Barokah. Penelitian dilakukan di agroindustri perkebunan teh rakyat kelompok tani Barokah Kecamatan Ciwidey Kabupaten Bandung. Data yang digunakan dalam penelitian ini terdiri atas data primer dan data sekunder. Data primer yang digunakan pada penelitian ini didapat dari hasil pengamatan langsung di lapangan dan wawancara langsung kepada objek penelitian. Data sekunder pada penelitian ini diperoleh dari pihak-pihak terkait seperti Kelompok Tani Barokah, agroindustri teh rakyat, Kantor Desa Lebak Muncang. Selain dari yang sudah disebutkan di atas, peneliti juga menggunakan data sekunder dari studi literatur, jurnal, penelitian terdahulu. Metode analisis menggunakan multidimensional scaling (MDS). Hasil penelitian menunjukan hasil evaluasi keberlanjutan agroindustri perkebunan teh rakyat kelompok tani Barokah, menujukkan semua dimensi yaitu ekologi, ekonomi, sosial, kelembagaan dan teknologi pada kategori cukup.
\end{abstract}

Kata kunci: perkebunan teh, keberlanjutan, multidimensional scaling (MDS)

\section{ABSTRACT}

The tea commodity has an important role in the Indonesian economy, namely as an absorption of labor, a source of income for farmers, foreign exchange, encouraging agro-industrial development and environmental conservation. The purpose of this study is to determine and evaluate the sustainability status of the Barokah farmer group's tea plantations. The research was conducted in the tea plantation agro-industry of the Barokah farmer group, Ciwidey District, Bandung Regency. The data used in this study consisted of primary data and secondary data. Primary data used in this study were obtained from direct observations in the field and direct interviews with the object of research. Secondary data in this study were obtained from related parties such as the Barokah Farmer Group, the people's tea agro-industry, the Lebak Muncang Village Office. Apart from what has been mentioned above, researchers also use secondary data from literature studies, journals, previous research. The analysis method uses multidimensional scaling (MDS). The results showed the evaluation results of the agro-industrial sustainability of the Barokah farmer groups' tea plantations, showing all dimensions, namely ecological, economic, social, institutional and technological in the sufficient category.

Keywords: tea plantation, sustainability, multidimensional scaling (MDS). 


\section{PENDAHULUAN}

Perkebunan merupakan salah satu sub sektor pertanian yang memiliki peran yang cukup penting dalam pembangunan pertanian Indonesia. Perkebunan yang sudah lama dibudidayakan di Indonesia adalah teh, perkebunan teh merupakan salah satu komoditas utama sektor perkebunan. Teh dijadikan bahan minuman penyegar yang sejak dulu dikenal dan sudah membudaya dalam kehidupan masyarakat Indonesia.

Beberapa kandungan senyawa kimia pada teh dapat memberi kesan warna, rasa dan aroma yang memuaskan peminumnya. Sampai saat ini teh tetap merupakan salah satu minuman penyegar yang disukai. Selain sebagai bahan minuman, teh juga banyak digunakan untuk keperlukan obat-obaran dan kosmetik (Indarti, 2015). Komodistas teh mempunyai andil penting dalam perekonomian Indonesia yaitu sebagai sumber pendapatan petani, penyerapan tenanga kerja, devisa negara, mendorong agroindustri pengembangan wilayah dan pelestarian lingkungan. (Direktorat Jendral Perkebunan, 2014).

Saat ini Indonesia menempati peringkat keenam sebagai negara yang memiliki lahan teh terlusas di dunia setelah Tiongkok, India, Sri Langka,
Kenya dan Vietnam (Indarti, 2019). Jenis perkebunan teh di Indonesia dibagi menjadi tiga jenis berdasarkan status kepemilikan, yaitu perkebunan rakyat $(\mathrm{PR})$, perkebunan besar negara $(\mathrm{PBN})$, dan perkebunan besar swasta (PBS). Luas areal teh di Indonesia selama tahun 20152019 cenderung menurun, tahun 2019 perkebunan teh di Indonesia tercatat seluas 113.030 Ha. Dari ketiga status kepemilikan lahan tersebut lahan terluas dikelola oleh perkebunan rakyat dengan luas 51.874 Ha diikuti oleh perkebunan besar negara dengan luas $33.145 \mathrm{Ha}$ kemudian perkebunan besar swasta seluas $28.011 \mathrm{Ha}$.

Desa di Kecamatan Ciwidey yang memiliki produksi teh tertinggi adalah desa Rawabogo diikuti oleh Desa Lebak Muncang dan Panundaan, dari seluruh desa di Kecamatan Ciwidey, Desa Lebak muncang memiliki satu agroindustri teh rakyat yang masih bertahan hingga saat ini yaitu Agroindustri Kelompok Tani Barokah. Agroindustri ini memiliki jumlah anggota kelompok tani sebanyak 26 orang dan memiliki luas lahan seluas $50 \mathrm{Ha}$, dimana $35 \mathrm{Ha}$ merupakan perkebunan rakyat dan $15 \mathrm{Ha}$ merupakan lahan pribadi. Pada kebun yang ada, 45 Ha ditanami teh hijau dengan klon TRI 2024 dan 5 Ha ditanami teh putih dengan 
klon. Pada tahun 2007 agroindustri Barokah pernah melakukan ekspor ke berbagai negara di asia tetapi terhenti karena harga jual yang tidak menemui kesepakatan dari kedua pihak.

Menurut Trimo (2017), kendala yang dihadapi dalam mengembangkan agroindustri teh rakyat yaitu: 1) Kurangnya ketersediaan pucuk teh sebagai bahan baku agroindustri, 2) kurangnya pengetahuan untuk meningkatkan nilai tambah teh Pucuk, 3) Kurangnya kemampuan dalam penyediaan modal dan peralatan dalam mengolah pucuk teh, dan 4) masih kurangnya dukungan pemerintah dalam mempromosikan teh olahan rakyat.

Pada Agroindustri Teh Barokah terdapat beberapa masalah yang dihadapi yaitu: 1) produksi teh yang tidak stabil karena kondisi cuaca yang tidak menentu mengakibatkan pertumbuhan pucuk teh di kebun tidak optimal, hal ini menyebabkan agroindustri Barokah mengalami kekurangan bahan baku 2) kekurangan mesin penggilingpun menjadi masalah untuk melakukan produksi yang lebih tinggi, setiap harinya masih hanya bisa memproduksi $250 \mathrm{~kg} / \mathrm{hari}$ teh hijau.3) tidak terdapatnya peraturan tertulis (SOP) produksi teh di pabrik, sehingga bisa mengakibatkan kesalahan dalam proses produksinya. 4) mutu pucuk teh yang diperoleh pada bagian perkebunan tidak menentu, sehingga agroindustri membeli bahan baku dari kelompok Tani Maju yang menjual hasil petiknya pada agroindustri Barokah.

Kekurangan bahan baku untuk proses produksinya dipenuhi dengan cara membeli teh dari Cukul di Pangalengan dan membeli teh keringan yang belum disortir. Namun, kualitas teh yang didapat terkadang tidak sesuai yang keinginan pabrik.

Menurut Trimo, et al. (2019), pengembangan produk hilir teh rakyat bernilai tambah tinggi akan mampu meningkatkan nilai ekonomis teh Indonesia, khususnya teh yang berasal dari rakyat. Hal tersebut merupakan salah satu alternatif untuk meningkatkan harga jual teh rakyat, yang akhirnya dapat meningkatkan pendapatan petani teh dan akan berdampak terhadap keberlangsungan agroindustri teh.

Keberadaan agroindustri perkebunan teh diharapkan menjadi salah satu pengerak pembangunan dan berperan penting dalam pembangunan daerah khususnya bidang ekonomi, dengan adanya agroindustri perkebinan teh dilingkungan pedesaan diharapkan dapat meningkatkan permintaan terhadap 
komoditas pertanian yang dijadikan barang yang lebih berguna bagi kebutuhan masyarakat. Secara umum tujuan penelitian ini untuk menilai atau mengevaluasi status keberlanjutan pengolahan perkebunan teh kelompok tani Barokah.

\section{METODE PENELITIAN}

\section{Pengumpulan Data dan Analisis}

Pada penelitian ini digunakan desain penelitian mix method dimana menurut Creswell (2018), mix method merupakan pendekatan penelitian yang mengkombinasikan bentuk penelitian kualitatif dan kuantitatif. Penelitian deskriptif kualitatif. Menurut Sugiyono (2012), penelitian kualitatif adalah penelitian yang berdasarkan pada filsafat post positivisme, digunakan untuk meneliti pada kondisi objek yang alamiah, dimana peneliti adalah sebagai instrument kunci. Penggunaan pendekatan desktrif kualitatif karena penelitian ini merupakan studi kasus yang melihat banyak variabel yang harus diperhatikan untuk mendapatkan gambaran dan keterangan-keterangan mengenai objek penelitian.

Sumber data yang digunakan dalam penelitian ini terdiri atas data primer dan data sekunder. Menurut Sugiyono (2012), data primer adalah data yang didapat dari hasil wawancara dengan menanyakan sesuai dengan daftar pertanyaan yang telah dipersiapkan terlebih dahulu oleh peneliti. Data primer yang digunakan pada penelitian ini didapat dari hasil pengamatan langsung di lapangan dan wawancara langsung kepada objek penelitian yaitu ketua Kelompok Tani Barokah sebagai informan yang dipilih dengan sengaja (purposive). Hal tersebut dilakukan atas dasar pertimbangan bahwa ketua kelompok tani Barokah dianggap paling mengetahui tentang informasi yang dibutuhkah oleh peneliti.

Menurut Sugiyono (2012), data sekunder merupakan sumber data yang diperoleh dengan cara membaca, mempelajari dan memahami melalui media lain yang bersumber dari literatur, buku-buku, serta dokumen. Data sekunder pada penelitian ini diperoleh dari pihak-pihak terkait seperti Kelompok Tani Barokah, agroindustri teh rakyat, Kantor Desa Lebak Muncang. Selain dari yang sudah disebutkan diatas peneliti juga menggunakan data sekunder dari studi literatur, jurnal, penelitian terdahulu. 


\section{METODE ANALISIS}

Analisis multidimensional scaling (MDS) merupakan salah satu teknik analisis data yang banyak digunakan dalam berbagai bidang keilmuan seperti pemasaran, sosiologi, fisika, ilmu politik, dan biologi yang juga merupakan salah satu metode "multivariate" yang dapat menangani data teknik statistika untuk memvisualisasikan ketidakserupaan (dissimilarity) dari obyek penelitian yang bersifat kuantitatif (metric) maupun kualitatif (non metric) ke dalam ruang berdimensi rendah atau metode ordinasi dalam ruang (dimensi) yang diperkecil. Ordinal sendiri merupakan proses yang berupa "plotting" titik obyek (posisi) di sepanjang sumbu-sumbu yang disusun menurut hubungan tertentu dalam sebuah system grafik yang terdiri atas atau lebih sumbu (Legendre 1983). Dalam MDS, obyek direpresentasikan sebagai titik dimana semakin dekat jarak antar titik, maka semakin besar keserupaannya (similarity). Ukuran yang digunakan untuk mengukur hubungan antar obyek adalah proximity yang berarti kedekatan obyek yang satu dengan yang lainnya. Kegunaan MDS adalah untuk menyajikan obyek-obyek secara visual berdasarkan kemiripan yang dimiliki. Selain itu, kegunaan lain dari teknik ini adalah mengelompokkan obyek yang memiliki kemiripan dilihat dari beberapa peubah yang dianggap mampu mengelompokkan obyek-obyek tersebut (Wickelmaier 2003).

Multidimensional scaling berkaitan dengan permasalahan bahwa untuk sejumlah asosiasi yang diamati antara setiap pasang $\mathrm{N}$ obyek, ditemukan sebuah wakil asosiasi dari obyek tersebut dalam dimensi yang diperkecil sedemikian sehingga dugaan wakil asosiasi obyekobyek ini hampir sama dengan asosiasi awal (Johnson dan Wichern, 1988 ). Ketika asosiasi diukur dalam skala interval atau rasio maka metodenya disebut metric multidimensional scaling dan jika data diukur dalam skala ordinal atau nominal maka metode analisisnya disebut nonmetric multi dimensional scaling. Jarak yang dipertahankan dalam hal ini adalah urutan peningkatan jarak, karena jarak dari obyek yang diukur secara nonmetrik tidak memenuhi persyaratan jarak yang metrik, yaitu:

1. Jika $a=b$, maka $D(a, b)=0$

2. Jika $a \neq D(b, a)>0$

3. $\mathrm{D}(\mathrm{a}, \mathrm{b})=\mathrm{D}(\mathrm{b}, \mathrm{a})$

4. $\mathrm{D}(\mathrm{a}, \mathrm{b})+\mathrm{D}(\mathrm{b}, \mathrm{c}) \geq \mathrm{D}(\mathrm{a}, \mathrm{c})$

Penyimpangan karakteristik jarak setelah ordinasi dibandingkan dengan sebelum ordinasi diukur dalam sebutan 
"stress" yakni \% penyimpangan dari karakteristik awal. Makin kecil nilai stress berarti makin besar representasi jarak dapat dipertahankan pada analisis ordinasi dalam ruang yang diperkecil atau hasil analisis makin dapat dipercaya. Nilai stress $=10$ persen dianggap cukup sedang; stress $=20$ persen dianggap kurang (Johnson dan Wichern 1988). Namun demikian dengan pendekatan RAPFISH penggunaan kriteria stress $\leq$ 25 persen untuk dapat menerima hasil analisis multidimensional scaling. Nilai stress akan sangat dipengaruhi oleh dimensi akhir yang dibuat, makin besar dimensi akhir yang dibuat makin kecil nilai stress.

Skor perkiraan setiap dimensi dinyatakan dengan skala terburuk (bad) 0 persen sampai yang terbaik (good) 100 persen, yang dikelompokkan ke dalam empat kategori, yaitu: 0-25 persen dikategorikan buruk (tidak berkelanjutan), 25,01-50 persen (kurang berkelanjutan), 50,01-75 persen (cukup berkelanjutan) dan 75,01-100 persen dikategorikan baik (sangat berkelanjutan).

$$
\text { Selanjutnya nilai indeks }
$$
keberlanjutan pengelolaan agroindustri erkebunan teh rakyat kelompok tani Barokah, setiap dimensi (ekologi, ekonomi, sosial, kelembagaan dan teknologi) kemudian dapat divisualisasikan melalui diagram layang. Teknik ordinasi atau penentuan jarak di dalam MDS didasarkan pada Euclidian Distances yang dalam ruang berdimensi $n$ dapat ditulis sebagai berikut:

$$
\begin{aligned}
& d=\sqrt{\left(I x_{1}-x_{2} I^{2}+I y_{1}-y_{2} I^{2}\right)}+ \\
& \left(I x_{1}-x_{2} I^{2} \ldots .\right)
\end{aligned}
$$

Analisis Rap ini dapat memungkinkan untuk menganalisis leverage (senstivitas dari pengurangan atribut terhadap skor keberlanjutan). Leverage dihitung berdasarkan standard error (SE) perbedaan antara skor dengan atribut dan skor yang diperoleh tanpa atribut. Perbedaan SE semakin kecil maka semakin baik.Teknik yang digunakan untuk meregresikan persamaan di atas adalah Algoritma ALSCAL (Alder et al, 2000), merupakan metode yang paling sesuai untuk RAPFISH dan mudah tersedia pada hampir setiap software statistika (SPSS dan SAS). Metode ALSCAL mengoptimisasi jarak kuadrat (square distance $=\mathrm{d}$ ijk ) terhadap data kuadrat (titik asal $=0$ ijk ), yang dalam tiga dimensi ( $i, j, k)$ ditulis dalam formula yang disebut S-Stress sebagai berikut: 


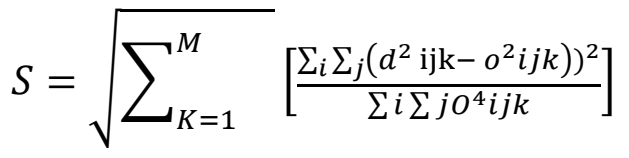

Jarak kuadrat merupakan jarak euclidian yang dibobot atau ditulis:

$$
d^{2}=\sum_{a=i}^{r} w_{k a}\left(x_{i a}-x_{j a}\right)^{2}
$$

Goodness of fit dalam MDS dicerminkan dari besaran nilai S-Stress yang dihitung berdasarkan nilai $\mathrm{S}$ di atas dan R 2 . Nilai stres yang rendah menunjukkan good fit, sedangkan nilai $\mathrm{S}$ yang tinggi menunjukkan sebaliknya. Di dalam Rapfish, model yang baik ditunjukkan oleh nilai stres yang lebih kecil dari 0,25 $(\mathrm{S}<0,25)$, sedangkan nilai R2 yang baik adalah yang nilainya mendekati 1 (Malhotra, 2006).

\section{Analisis Monte Carlo}

Analisis Monte Carlo digunakan untuk mengevaluasi pengaruh kesalahan galat acak (random error) pada proses (Kavanagh \& Pitcher, 2004). Menurut Kavanagh dan Pitcher (2004), prosedur analisis ini diperlukan untuk mengetahui pengaruh kesalahan pembuatan skoring/penilaian atribut oleh pengetahuan yang kurang memadai dari responden atau kesalahan dalam memahami atribut dan petunjuk penilaian, pengaruh variasi pemberian skor karena perbedaan pendapat atau penilaian oleh orang yang berbeda, stabilitas metode MDS yang berulangulang, tingginya nilai stress hasil analisis, serta kesalahan input data atau adanya data yang hilang (missing data), tingginya nilai stress hasil analisis dengan nilai stress dapat diterima apabila $<20 \%$ (Pitcher and Preikshot 2001). Jika perbedaan antara hasil perhitungan MDS dan Monte Carlo kurang dari 1, maka sistem yang dikaji cukup bagus atau sesuai dengan kondisi nyata (Kavanagh dan Pitcher, 2004; Fauzi dan Anna, 2005).

\section{Analisis Sensitivitas}

Mengacu pada nilai indeks keberlanjutan kehidupan masyarakat, maka tahap selanjutnya dilakukan analisis sensitivitas. Analisis sensitifitas dimaksudkan untuk dapat mendeteksi atribut yang paling sensitif memberikan kontribusi pada pengelolaan perkebunan teh kelompok tani Barokah, untuk melihat peranan setiap atribut terhadap keberlanjutan dilakukan dengan "analisis leverage" yaitu perubahan ordinasi jika setiap parameter tertentu dihilangkan dari analisis. Pengaruhnya dapat dilihat dalam bentuk perubahan "root mean square" (RMS) ordinasi yang terdapat pada sumbu sustainabilitas. Jika nilai perubahan RMS akibat hilangnya satu 
atribut adalah besar, ini menunjukan atribut tersebut mempunyai kontribusi besar terhadap keberlanjutan, (sangat sensitif atribut tersebut terhadap keberlanjutan kehidupan masyarakat), sebaliknya jika satu atrbut dikeluarkan dari analisis namun hasilnya tidak mengalami perubahan secara signifikan, maka tingkat sensitifitas atribut tersebut sangat kecil (tidak berpengaruh). Analisis sensitivitas dilakukan untuk melihat atribut yang paling sensitif atau indikator kunci dalam memberikan kontribusi terhadap indeks keberlanjutan pengelolaan perkebunan teh rakyat kelompok tani Barokah Atribut/indikator yang paling sensitif terlihat dari perubahan root mean square (RMS). Setiap perubahan atribut sensitif atau indikator kunci akan mempengaruhi nilai indeks keberlanjutan, yaitu semakin besar nilai RMS maka semakin sensitif atribut tersebut berpengaruh terhadap pengelolaan berkelanjutan.

Prosedur Rap untuk pengelolaan perkebunan teh rakyat kelompok tani Barokah disajikan pada Gambar 1.

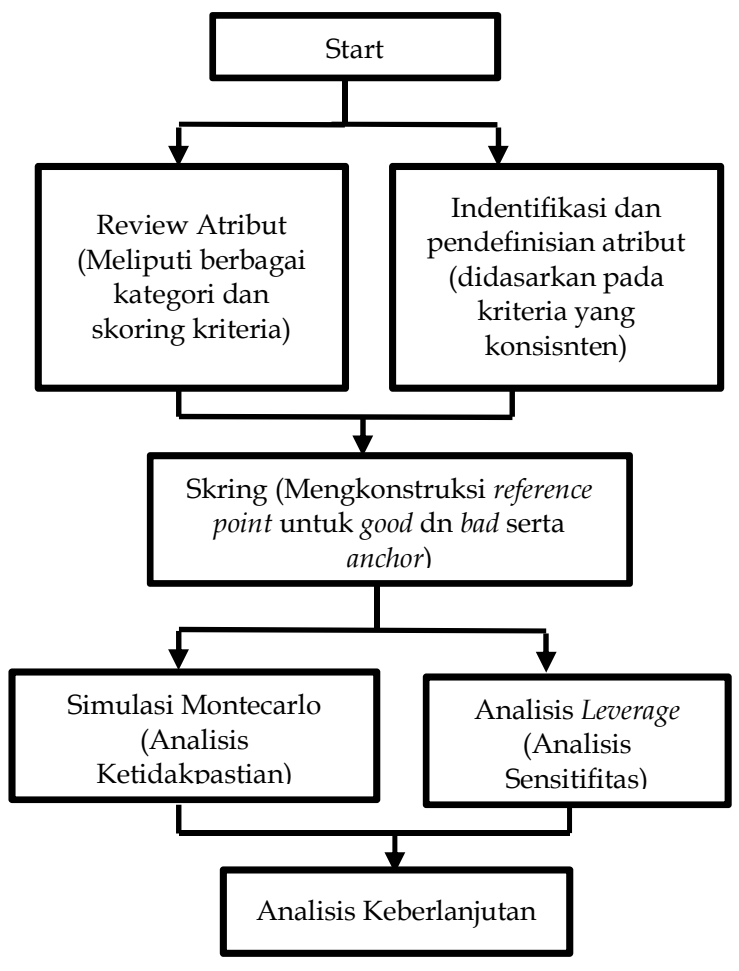

Gambar 1 Elemen proses aplikasi Rapfish

\section{HASIL DAN PEMBAHASAN}

Kondisi Umum Agroindustri Teh Rakyat Kelompok Tani Barokah

Pada mulanya pabrik agroindustri teh rakyat kelompok tani Barokah merupakan usaha milik keluarga, yang bergerak di bidang agroindustri teh yang didirikan oleh $\mathrm{H}$. Wildan Dharma Adiwijaya (yang saat ini menjadi Ketua Kelompok Tani Barokah) yang didirikan pada tahun 1980 dengan nama pabrik CV.Wijaya Tea.

Pada tahun 2004, petani yang berada di Desa Lebak Muncang berinisiatif untuk membentuk kelompok tani, yaitu "Kelompok Tani Barokah" 
guna menyalurkan hasil tani mereka agar tidak menjualnya ke tengkulak. Setelah dibentuknya kelompok tani akhirnya pabrik yang awalnya dikelola sendiri kemudian dikelola oleh Kelompok Tani Barokah, sehingga menjadi Agroindustri Teh Rakyat Kelompok Tani Barokah.

Saat ini jumlah anggota anggota kelompok Tani Barokah adalah 26 orang yang dipimpin oleh $\mathrm{H}$ Wildan sebagai ketuanya. Agroindustri teh rakyat Kelompok Tani Barokah memiliki kebun teh seluas $50 \mathrm{Ha}$ yang terdiri atas $45 \mathrm{Ha}$ komoditas teh hijau dan 5 Ha komoditas teh putih. Agroindustri ini merupakan pengolahan teh rakyat yang memiliki kegiatan menghasilkan pucuk teh dari kebun sendiri maupun dari kebun rakyat untuk kemudian diolah menjadi teh yang sesuai dengan keinginan pasar. Saat ini, produk teh yang diproduksi oleh agroindustri teh rakyat Kelompok Tani Barokah memiliki merek Pucuk Sari.

Agroindustri teh rakyat Kelompok Tani Barokah mempunyai tugas dan kewajiban yaitu untuk membina petani, memberikan pelatihan cara pemetikan, cara berkebun dan mengolah kebun yang baik dan cara berorganisasi, memberdayakan petani, mengolah teh rakyat, memasarkan produk teh rakyat. Beberapa misi yang dimiliki oleh agroindustri teh rakyat ini diantaranya adalah membina petani teh rakyat yang tergabung dalam Kelompok Tani Barokah dan menambah pengetahuan petani teh rakyat mengenai pengolahan teh juga terus mengembangkan kebun teh rakyat. Diharapkan dari misi tersebut dapat mempertahankan dan mengembangkan kebun teh rakyat. Dari visi dan misi tersebut maka tujuan adalah menghasilkan produk teh kering yang dapat memenuhi permintaan pasar.

\section{Keadaan Dimensi Keberlanjutan Agroindustri Perkebunan Teh Kelompok Tani Barokah}

Penentuan indeks keberlanjutan wilayah berbasiskan perkebunan teh rakyat kelompok tani Barokah berdasarkan pada lima dimensi keberlanjutan, yaitu dimensi ekologi, ekonomi, sosial, kelembagaan dan teknologi, dengan atribut dan nilai keberlanjutan tiap dimensi. Berikut penjelasan dari setiap dimensi keberlanjutan Agroindustri kelompok tani Barokah.

\section{Dimensi Ekologi}

Hasil analisis ordinasi MDS pada dimensi ekologi berpengaruh terhadap tingkat keberlanjutan. Atribut pada dimensi ekologi yaitu pengolahan lahan, pengolaan air, proses produksi ramah 
lingkungan, potensi pembukaan lahan baru, pembokaran tanaman tua, kesesuaian lahan, konservasi lahan dan pembuangan limbah. Besarnyanya indeks keberlanjutan pada dimensi ekologi dipengaruhi oleh atribut-atribut tersebut, namun nilai atribut memberikan pengaruh yang berbeda-beda. Hasil nilai keberlanjutan pada dimensi ekologi sebesar 57,19. Nilai tersebut pada kategori cukup, hal ini dikarenakan pengolahan lahan sangat baik dilakukan oleh kelompok tani Barokah sehingga tanah yang ditanami teh berkondisi baik dan dapat menghasilkan produk teh yang baik dan pengolahan limbah produksi teh di pabrik dikelola dengan sangat baik sehingga tidak mencemari lingkungan sekitar, untuk skala keberlanjutan dapat dilihat pada Gambar 2.

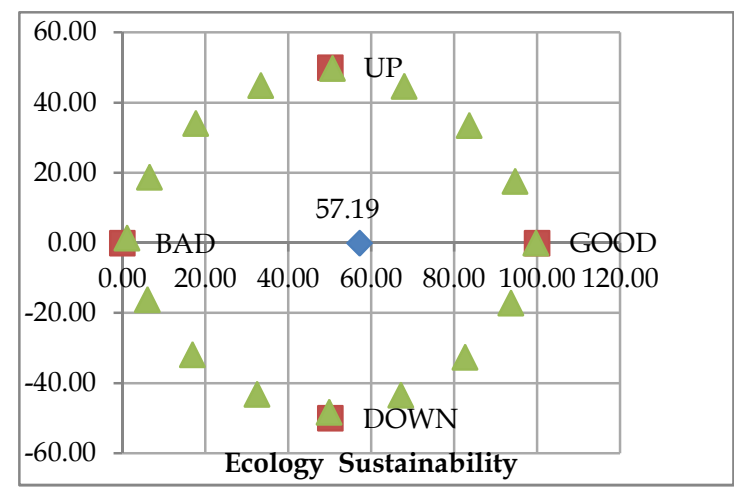

Gambar 2 Nilai indeks dan status keberlanjutan dimensi ekologi

Pada analisis leverage dilakukan untuk mengetahui atribut yang sensitif terhadap keberlanjutan pengelolan agroindustri perkebunan teh rakyat kelompok tani Barokah pada dimensi ekologi. Berdasarkan analisis leverage dimensi ekologi diperoleh atribut yang sensitif terhadap sensitif terhadap indeks keberlanjutan yaitu pembuangan limbah, pembongkaran tanaman tua dan pengolahan lahan. Hasil analissi leverage dapat dilihat pada Gambar 3 .

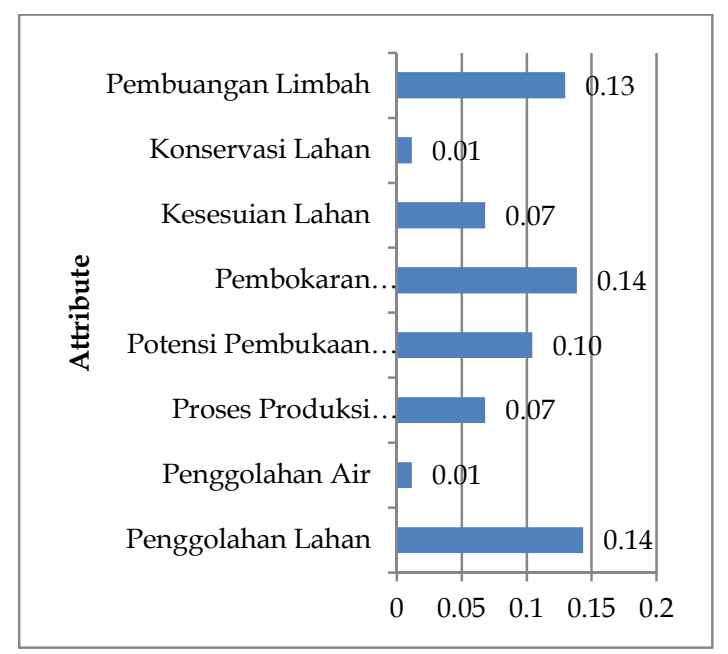

Gambar 3 Nilai sensitivitas atribut dimensi ekologi yang dinyatakan dalam perubahan Road Mean Square (RMS) skala keberlanjutan 0-100

\section{Dimensi Ekonomi}

Hasil analisis ordinasi MDS pada dimensi ekonomi berpengaruh terhadap tingkat keberlanjutan. Atribut pada dimensi ekonomi yaitu harga teh,jumlah tenaga kerja, kontribusi penguasaan lahan perkebunan, perubahan upah rill, kelayakan usaha, produktivitas hasil perkebunan, kesempatan kerja, kemitraan usaha dan tingkat kesejahteraan masyarakat. Besarnyanya indeks keberlanjutan pada dimensi ekonomi dipengaruhi oleh atribut-atribut tersebut, 
namun nilai atribut memberikan pengaruh yang berbeda-beda. Hasil nilai keberlanjutan pada dimensi ekonomi sebesar 53,36. Nilai tersebut pada kategori cukup, hal ini merupakan dengan adanya industri pabrik produksi teh berdampak kepada masyarakat sekitar wilayah pabrik antara lain tingkat kesejahteraan masyarakat meningkat dengan menyerap tenaga kerja di kalangan sekitar sehingga membuka peluang masyrakat untuk bekerja di Industri teh, untuk skala keberlanjutan dapat dilihat pada Gambar berikut.

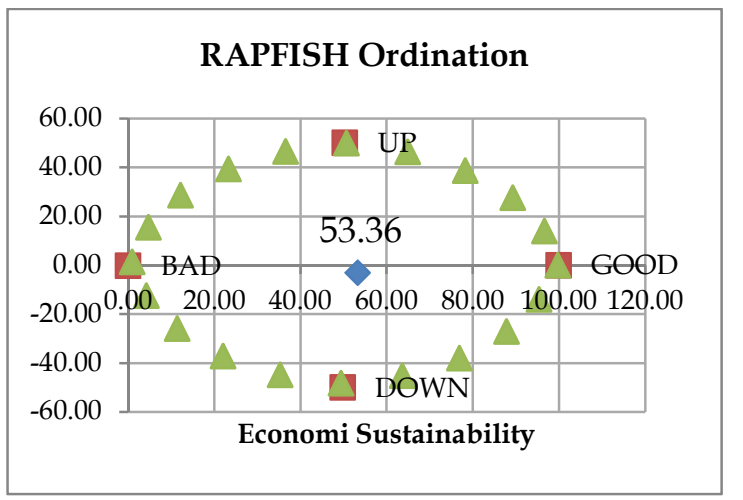

Gambar 4 Nilai indeks dan status keberlanjutan agroindustri perkebunan teh rakyat kelompok tani Barokah

Pada analisis leverage dilakukan untuk mengetahui atribut yang sensitif terhadap keberlanjutan pengelolan agroindustri perkebunan teh rakyat kelompok tani Barokah pada dimensi ekonomi. Berdasarkan analisis leverage dimensi ekonomi diperoleh 1 atribut yang sensitif terhadap sensitif terhadap indeks keberlanjutan yaitu perubahan upah ril.
Hasil analissi leverage dapat dilihat pada Gambar 5.

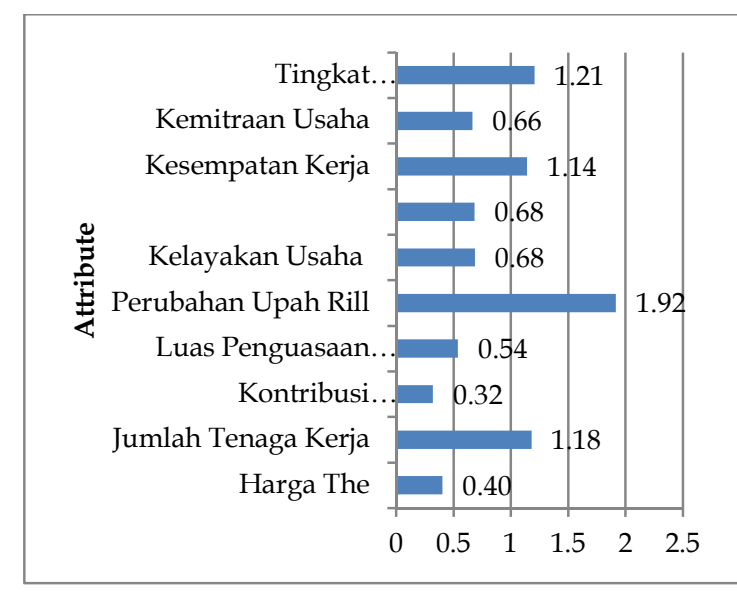

Gambar 5 Nilai sensitivitas atribut dimensi ekonomi yang dinyatakan dalam perubahan Road Mean Square (RMS) skala keberlanjutan 0-100

Berdasarkan hasil analisis pada atribut kelayakan agroindustri perkebunan teh rakyat kelompok tani Barokah memperlihatkan secara ekonomi layak untuk dikembangkan karena memberikan keuntungan yang cukup untuk petani. Dimensi ekonomi pada ketagori cukup, hal ini disebabkan oleh menurunya produksi teh dan penjualan produk teh di agroindustri kelompok tani Barokah, setahun belakangan permintaan teh hijau agroindustri kelompok tani Barokah mengalami penurunan disebabkan oleh banyaknya pesaing dalam menjual produk teh. Untuk meningkatkan keuntungan agroindustri dibutuhkan keterlibatan semua pihak terutama pihak pemerintah untuk mengembangkan brand lokal. 
Perolehan nilai atribut tertinggi terdapat pada perubahan upah rill, hal ini merupakan pekerja di agroindustri mengalami peningkatan pendapatan setiap tahunnya, mayoritas pekerja dari warga sekitar pabrik sehingga dapat membuka lapangan pekerjaan bagi warga setempat, sedangkan nilai terendah pada atribut dimensi ekonomi yaitu kontribusi penguasaan perkebunan sebesar 0,32 , hal ini disebabkan kurangnya lahan untuk penanaman saat ini lahan yang dimiliki kelompok tani Barokah \pm 50 Hektar namun setiap tahunya mengalami penurunan produksi dan lahan.

\section{Dimensi Sosial}

Keberlanjutan usaha produksi teh sangat ditentukan oleh faktor sosial antara lain tingkat penerimaan para pelaku aktivitas produksi pucuk teh terhadap suatu masukan ataupun teknologi tertentu. Sebagai contoh penggunaan pupuk alam berupa limbah peternakan tertentu secara teknis akan sangat baik dalam mendukung keberlanjutan usaha tani teh, namun bagi masyarakat tertentu tidak dapat menerima teknologi tersebut sehingga tidak dapat berjalan. Yang lebih pokok yaitu bagaimana usaha tani teh dapat mensejahterakan pelaku agribisnis dan masyarakat pada umumnya. (Permentan, No.50 Tahun 2014).

Berdasarkan hasil analisis ordinasi MDS dimensi sosial berpengaruh terhadap keberlanjutan agroindustri perkebunan teh rakyat kelompok tani Barokah. Atribut dalam dimensi sosial terdiri penduduk bekerja disektor perkebunan, petani mendapatkan penyuluhan pertanian, pendidikan formal petani, aksesibitas transfortasi desa, jumlah petani teh, penduduk bekerja di sektor perkebunan, pertumbuhan penduduk dan penduduk berkerja di pabrik agroindustri. Nilai indeks keberlanjutan dimensi sosial sebesar 70,11 berada pada kategori cukup. Skala keberlanjutan dengan status keberlanjutan pada Gambar 6.

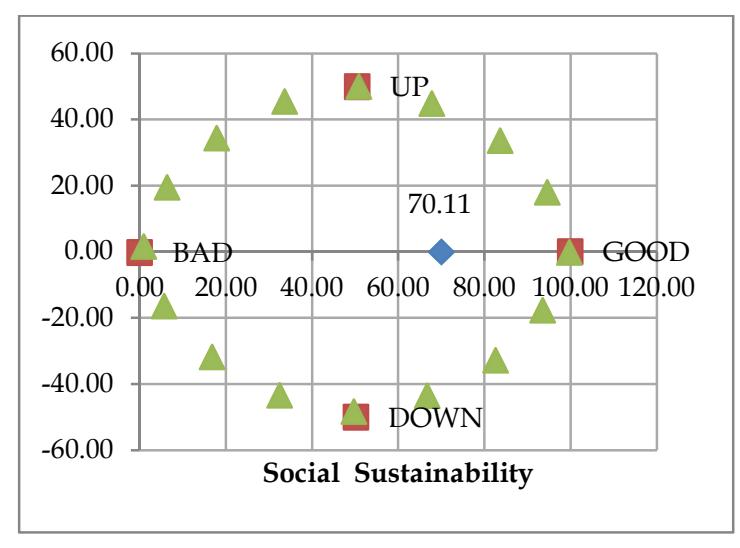

Gambar 6 Nilai Indeks dan Keberlanjutan dimensi sosial

Berdasarkan hasil analisis pada atribut kelayakan agroindustri perkebunan teh rakyat kelompok tani Barokah memperlihatkan secara sosial 
layak untuk dikembangkan karena memberikan dampak sosial terhadap lingkungan sekitar. Dimensi sosial pada ketagori cukup, hal ini disebabkan oleh dengan adanya pabrik teh mayolitas pekerja adalah warga sekitar pabrik dan akses transfortasi desa juga meningkat sehingga masyarakat sekitar bisa menjalankan aktifitas usahatani mereka.

Berdasarkan hasil analisis leverage diperoleh atribut yang sensitif yaitu : penduduk sebagaian besar bekerja di sektor perkebunan, pendidikan formal petani, jumlah petani teh dan aksesibilitas transfortasi desa. Hasil analisis leverage dapat dilihat pada Gambar 7.

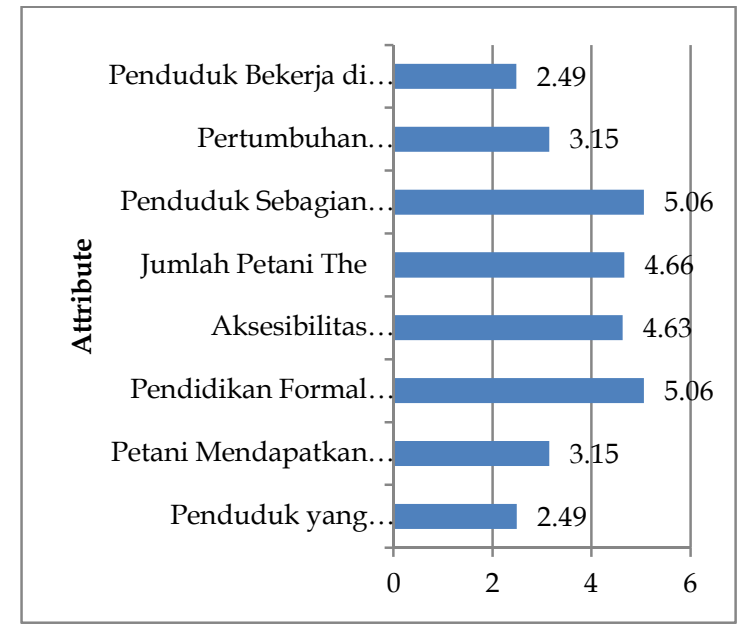

Gambar 7 Nilai sensitivitas atribut dimensi sosial yang dinyatakan dalam perubahan Root Mean Square (RMS) skala keberlanjutan 0-100

\section{Dimensi Kelembagaan}

Parameter kelembagaan merupakan indikator tersedianya lembaga penunjang dan mendorong keberlanjutan pemanfaatan SDA dan lingkungan sekitar lokasi agroindustri. Tegaknya peraturan, adat,tokoh masyarakat dan lembaga lain untuk menunjang keberlanjutan pemanfaatan SDA dan lingkungan. Ditinjau dari dimensi kelembagaan yaitu lembaga-lembaga keuagan untuk menunjukan kegiatan agroindustri dan lingkungan dan kelompok tani yang berkontribusi didalam kegiatan agroindustri perkebunan teh rakyat kelompok tani Barokah.

$$
\text { Menurut Nasution }
$$

kelembagaan merupakan suatu sistem organisasi dan kontrol terhadap suatu sumber daya yang dapat mengatur hubungan seseorang dengan yang lain. Pentingnya kelembagaan petani untuk bertujuan meningkatkan potensi petani dan meningkatkan daya saing kelompokkelompk tani (Kartasasmitra, 1997).

Berdasarkan hasil analisis ordinasi MDS dimensi kelembagaan berpengaruh terhadap keberlanjutan agroindustri perkebunan teh rakyat kelompok tani Barokah. Atribut dalam dimensi kelembagaan yaitu kemampuan modal kelembagaan kelompok tani, kelompok tani, lembaga keuangan, pemanfaatan lembaga pembiayaan, gapoktan, jumlah kelompok tani, akses petani ke yeknologi dan legal . Nilai indeks keberlanjutan dimensi kelembagaan sebesar 59,63 
berada pada kategori cukup. Skala keberlanjutan dengan status keberlanjutan pada Gambar 8.

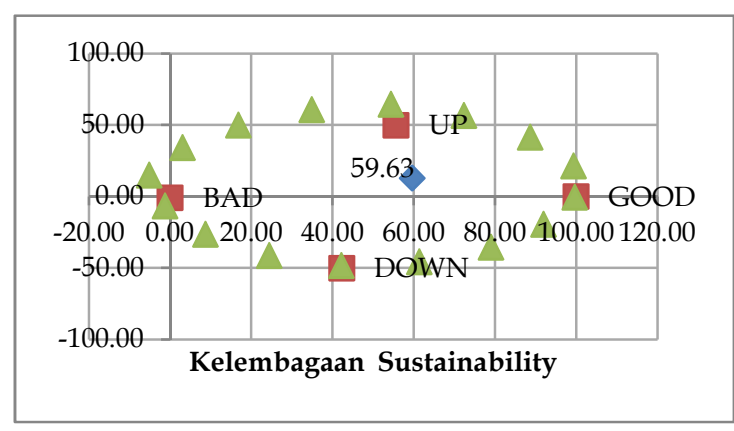

Gambar 8 Nilai Indeks dan Keberlanjutan dimensi kelembagaan

Berdasarkan hasil analisis pada atribut kelayakan agroindustri perkebunan teh rakyat kelompok tani Barokah memperlihatkan secara kelembagaan layak untuk dikembangkan karena memberikan dampak kelembagaan terhadap kelompok tani dan lembaga lainya. Dimensi kelembagaan pada ketagori cukup, hal ini disebabkan oleh kelembagan agroindustri dapat dimanfaatkan oleh petani sekitar dalam mengakses modal untuk membantu usahataninya. Begitu halnya dengan adanya kelompok tani dapat dimanfaatkan petani untuk mengali informasi dan pelatihan dalam menunjang usahatani. Atribut yang sensitif yang memberikan terhadap terhadap nilai indeks agroindustri perkebunan teh rakyat kelompok tani Barokah pada dimensi kelembagaan dengan melakukan analisis Leverage. Berdasarkan hasil analisis leverage diperoleh atribut yang sensitif yaitu : pemanfaatan lembaga pembiayaan, gapoktan, kelompok tani, lembaga keuangan dan jumlah kelompok tani. Hasil analisis leverage dapat dilihat pada Gambar 9.

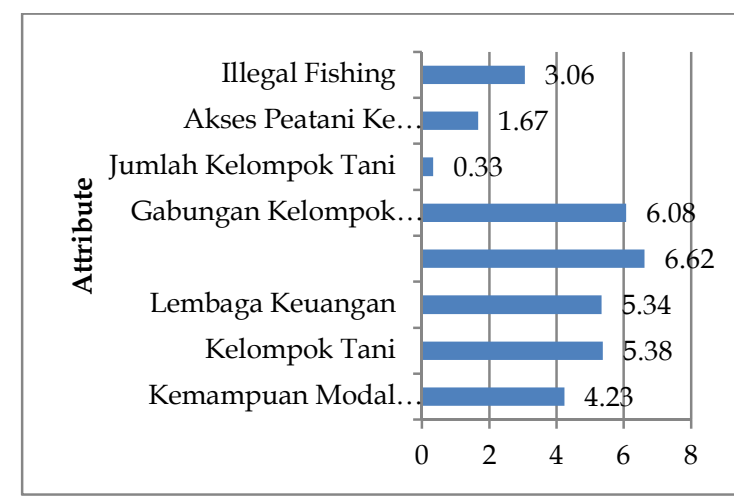

Gambar 9 Nilai sensitivitas atribut dimensi kelembagaan yang dinyatakan dalam perubahan Root Mean Square (RMS) skala keberlanjutan 0-100

\section{Dimensi Teknologi}

Parameter teknologi merupakan penerapan teknologi yang digunakan lembaga agroindustri untuk meningkatkan produksi. Indikator penerapan teknologi terdiri konservasi lahan, teknik penyiapan lahan, teknologi pengolahan lahan, teknologi budidaya (pembibitan, penanaman, pemeliharaan dan pemanenan), teknologi pengendalian hama, ketersedian teknologi pasca panen, teknologi produksi hasil panen dan teknologi informasi komoditi pertanian.

Berdasarkan hasil analisis ordinasi MDS dimensi teknologi berpengaruh 
terhadap keberlanjutan agroindustri perkebunan teh rakyat kelompok tani Barokah. Nilai indeks keberlanjutan dimensi teknologi sebesar 59,12 berada pada kategori cukup. Skala keberlanjutan dengan status keberlanjutan pada Gambar 10.

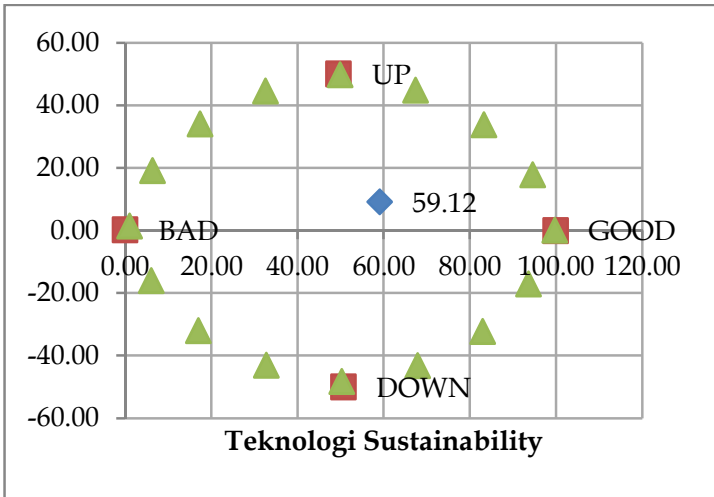

Gambar 10 Nilai Indeks dan Keberlanjutan dimensi teknologi

Berdasarkan hasil analisis pada atribut kelayakan agroindustri perkebunan teh rakyat kelompok tani Barokah memperlihatkan secara teknologi layak untuk dikembangkan karena memberikan kemudahan dalam memperoduksi teh baik dilahan dan pabrik. Dimensi teknologi ketagori cukup. Penerapan teknologi sudah diterapkan di perkebunan teh rakyat kelompok tani Barokah seperti menggunakan mesin teknologi pengolahan, budidaya sampai dengan pengolahan teh di pabrik. Atribut yang sensitif yang memberikan terhadap terhadap nilai indeks agroindustri perkebunan teh rakyat kelompok tani
Barokah pada dimensi teknologi dengan melakukan analisis Leverage. Berdasarkan hasil analisis leverage diperoleh atribut yang sensitif yaitu : komoditi pertanian dengan kesesuaian lahan, teknologi budidaya, teknologi penyiapan lahan dan teknologi pengolahan hasil panen. Hasil analisis leverage dapat dilihat pada Gambar 11.

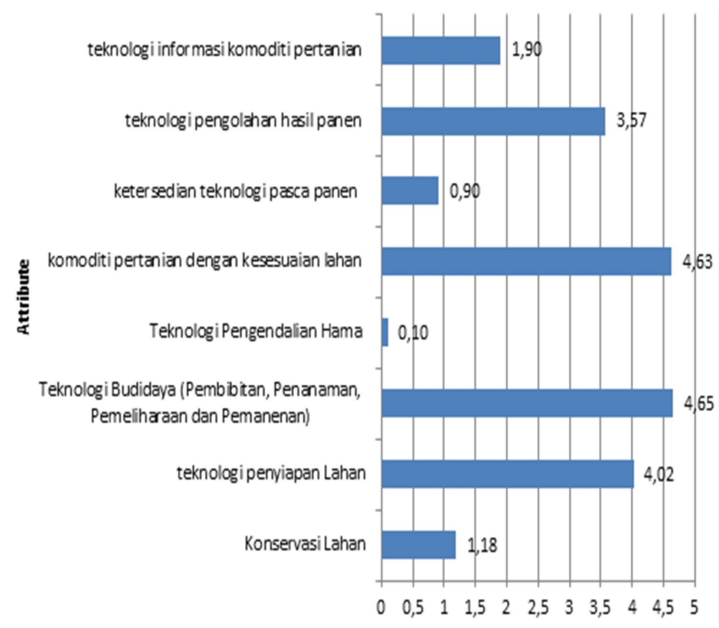

Gambar 11 Nilai sensitivitas atribut dimensi teknologi yang dinyatakan dalam perubahan Root Mean Square (RMS) skala keberlanjutan 0-100

\section{Nilai Stress dan Koefisien Determinasi}

Ketepatan konfigurasi dari suatu titik yang mencerminkan data aslinya dapat diukur dengan melihat nilai stress dari hasil analisis ordinasi Rap-Insus terhadap setiap dimensi yang dianalisis. Kemampuan setiap atribut untuk menjelaskan dan memberikan kontribusi terhadap keberlanjutan sistem yang dikaji dengan melihat nilai koefisien determinasi $\left(\mathrm{R}^{2}\right)$ setiap dimensi yang 
dianalisis. Nilai stress dan koefisien determinasi setiap dimensi disajikan pada Tabel 1 .

Tabel 1. Nilai stress dan koefisien determinasi pada Rap-Insus Agroindustri perkebunan teh rakyat kelompok tani Barokah

\begin{tabular}{lllll}
\hline \multicolumn{1}{c}{ Dimensi } & $\begin{array}{c}\text { Nilai Indeks } \\
\text { Keberlanjut } \\
\text { an }\end{array}$ & Stress & $\mathbf{R}^{\mathbf{2} * *)}$ & Iterasi \\
\hline Ekologi & 57,19 & 0,1589 & 0,93902 & 2 \\
Ekonomi & 53,36 & 0,1462 & 0,94724 & 2 \\
& & 7 & & \\
Sosial & 70,11 & 0,1414 & 0,94821 & 3 \\
Kelembagaan & 59,63 & 0,1434 & 0,94050 & 2 \\
Teknologi & 59,12 & 0,1482 & 0,94434 & 2 \\
\hline
\end{tabular}

\section{Berdasarkan Tabel 1,}

memperlihatkan bahwa nilai stress ratarata berada diantara 0.14 sampai 15 dan nilai $\mathrm{R}^{2}$ diantara 0.93 sampai 0,94 . Di dalam Rapfish, nilai stress dikatakan baik apabila nilainya di bawah 0.25 (Malhotra 2006), berarti nilai goodness of fit dalam MDS, yang menyatakan bahwa konfigurasi atribut dapat mencerminkan data aslinya, sehingga dapat dinyatakan bahwa indikator yang dikaji telah mencukupi, akurat, dan dapat dipertanggungjawabkan. Nilai $\mathrm{R}^{2} \quad 0.93$ sampai 0,94 menunjukkan bahwa atribut atau faktor-faktor yang dinilai pada setiap dimensi mampu menerangkan dan memberikan kontribusi 93-94 persen terhadap keberlanjutan sistem yang dikaji. Menurut Kavanagh (2001), nilai $\mathrm{R}^{2}$ yang baik apabila lebih besar dari 80 persen atau mendekati 100 persen.

\section{Pengaruh Galat}

Evaluasi pengaruh galat (Error) acak dengan menggunakan analisis Monte Carlo bertujuan untuk mengetahui: (a) pengaruh kesalahan pembuatan skor atribut, (b) pengaruh variasi pemberian skor, (c) stabilitas proses analisis MDS yang berulangulang, (d) kesalahan pemasukan atau hilangnya data (missing data), dan (e) nilai stress dapat diterima apabila $<20$ persen. Hasil analisis Monte Carlo terhadap semua dimensi disajikan tabel berikut.

Analisis Monte Carlo menunjukkan bahwa nilai indeks keberlanjutan pengelolaan perkebunan teh rakyat kelompok tani Barokah pada taraf kepercayaan 90 persen memperlihatkan bahwa hasil analisis MDS dengan Monte Carlo tidak mengalami perbedaan yang siginifikan yang memiliki tingkat kepercayaan tinggi. Berikut hasil analisis Monte Carlo disajikan pada Tabel 2.

Tabel 2. Hasil analisis Monte Carlo untuk nilai Rap-Insus Agroindustri perkebunan teh rakyat kelompok tani Barokah pada taraf kepercayaan 90 persen

\begin{tabular}{|c|c|c|c|}
\hline \multirow[b]{2}{*}{ Dimensi } & \multicolumn{2}{|c|}{ Indeks Keberlanjutan } & \multirow{2}{*}{$\begin{array}{c}\text { Perbedaan/ } \\
\text { selisih } \\
\text { (MDS-MC) }\end{array}$} \\
\hline & MDS & $\begin{array}{c}\text { Monte } \\
\text { Carlo } \\
\end{array}$ & \\
\hline Ekologi & 57,19 & 55,65 & 1,54 \\
\hline Ekonomi & 53,36 & 51,88 & 1,48 \\
\hline Sosial & 70,11 & 68,44 & 1,67 \\
\hline Kelembagaan & 59,63 & 57,94 & 1,69 \\
\hline Teknologi & 59,12 & 57,18 & 1,94 \\
\hline
\end{tabular}

Agroindustri perkebunan kelompok tani 
Barokah menunjukkan bahwa semua atribut yang dikaji terhadap status keberlanjutan pengelolaan perkebunan rakyat teh cukup akurat dan dapat dipertanggungjawabkan. Hal tersebut ditunjukkan oleh nilai stress yang dibawah angka 0.25 dan nilai koefisien determinasinya 0.90 . Hal ini sesuai dengan pendapat Fauzi dan Anna (2005) yang menyatakan bahwa hasil analisis cukup memadai apabila nilai stress lebih kecil dari 0.25 (25 persen) dan nilai koefisien determinasinya mendekati nilai 1,0 Sementara itu, selisih antara indeks keberlanjutan MDS dan indeks hasil analisis montecarlo berkisar 1,4 sampai 1,9 dengan rata-rata 1,67 lebih kecil dari 5\% yang menunjukkan bahwa rentang nilai indikator yang digunakan telah cukup sesuai (Kavanagh dan Pitcher 2001).

\section{KESIMPULAN DAN SARAN}

\section{Kesimpulan}

1. Nilai keberlanjutan agroindustri perkebunan teh rakyat kelompok tani Barokah secara multidimensi berkatogi cukup.

2. Hasil evaluasi keberlanjutan agroindustri perkebunan teh rakyat kelompok tani Barokah, menujukkan semua dimensi yaitu ekologi, ekonomi, sosial, kelembagaan dan teknologi pada kategori cukup.

\section{Saran}

1. Perlunya meningkatkan kualitas hasil produk teh dan meningkatkan sarana dan prasana dalam menunjang produksi produksi teh yang sudah dikelola.

2. Bagi pemerinta perlu mengambantu dalam saluran pemasaran agar penjualan hasil produksi teh dapat meningkatkan pendapatan petani dan industri teh, kemudian, kemudian peran pengawasan perlu dilakukan.

\section{DAFTAR PUSTAKA}

Industri Peternakan. Bogor: IPB Press. Creswell, John W. 2018. Research Design. Pendekatan Metode Kualitatif, Kuantitatif, Dan Campuran. Yogyakarta: Pustaka Pelajar.

Direktorat Jendral Perkebunan .2014. Peningkatan Produksi, Produktivitas dan Mutu Tanaman Rempah dan Penyegar Pedoman Teknis Pengembangan Tanaman Teh. Jakarta: Direktorat Jendral Perkebunan.

Fauzi A, Anna S. 2005. Pemodelan Sumberdaya Perikanan dan Kelautan UntukAnalisis Kebijakan. Jakarta (ID): Penerbit Gramedia Pustaka Utama.

Indarti, Diah. 2019. Buku Outlook Komoditas Perkebunan Teh. Jakarta: Pusat Data dan Sistem Informasi Pertanian Sekretariat 
Jenderal Kementerian Pertanian 2019.

Johnson RA, Wicher DW. 1988. Applied

Multivariate Statistical Analysis.

Second edition. New Jersey (US):

Prentice Hall.

Kavanagh P. 2001. Rapid Appraisal of

Fisheries (Rapfish) Project, Rapfish

Sofware Des Eruption (For

Microsoft Excell). Vancouver

(CA): Fisheries Centre.

Kementerian Pertanian [Kementan].

2014. Peraturan Menteri Pertanian

Nomor:

50/Permentan/OT.140/4/2014.

Pedoman Teknik Budidaya Teh yang Baik (ID): Kementerian Pertanian.

Legendre L, Legendre P. 1983. Numerical Ecology. Development in environmental modeling, 3. Amsterdam (NL) : Elsevier Scientific Publishing Company.

Malhotra, N. K. 2006. Riset Pemasaran : Pendekatan Terapan. Jakarta (ID): PT Indeks Gramedia
Pitcher TJ, Preikshot D. 2004. RAPFISH: A Rapid Apraisall Technique to Evaluate the Sustainability Status of Fisheries. Vancouver (CA): Fisheries Centre.

Sugiyono. 2012. Metode Penelitian Kuantitatif. Yogyakarta: Alfabeta.

Wickelmaier F. 2003. An introduction to MDS [paper]. Denmark (DK): Sound quality research unit, Aalborg University.

Trimo, Lucyana, and Ilis Nurafifah. (2017). "Kajian potensi pengembangan agrowisata teh rakyat." Jurnal Penelitian Teh dan Kina 20(1) 36-47.

Trimo, Lucyana, Syarif Hidayat, and Muhammad Arief Budiman. 2019. "Beberapa Faktor Penentu Keberlanjutan Usaha Agroindustri Teh Rakyat." Jurnal Pemikiran Masyarakat Ilmiah Berwawasan Agribisnis 46-59. 